\title{
Pembangkit Listrik Tenaga Biogas dengan Digester Tipe Balon di Peternakan Sei Temiang Batam
}

\author{
Qoriatul Fitriyaha,", Dedi Irawan $^{\mathrm{b}}$ and Muhammad Prihadi Eko Wahyudia \\ a) Politeknik Negeri Batam \\ Jurusan Teknik Elektro \\ b) PT Epson Indonesia \\ Mukakuning Batam \\ *Email: fitriyah@polibatam.ac.id
}

\begin{abstract}
Abstrak
Peternakan sapi di Sei Temiang Batam menghasilkan kotoran sapi sebesar $\pm 50 \mathrm{~m}^{3}$ per bulan. Selama ini sebagian dari kotoran tersebut diambil oleh warga untuk dimanfaatkan sebagai bahan baku pupuk. Untuk menambah nilai jual limbah, tinja sapi juga bisa diolah menjadi sumber listrik alternatif sebelum dimanfaatkan ampasnya untuk rabuk organik. Penelitian ini menggunakan tipe balon sebagai digester pembangkit listrik biogas dengan alasan instalasinya sederhana, mudah dibongkar pasang dan harganya relatif murah. Prototype pembangkit ini menggunakan campuran kotoran sapi dan air dengan perbandingan 1:1. Gas sebesar 624 liter bisa dihasilkan dari satu drum plastik yang mampu untuk menyalakan listrik selama 35 menit dengan kapasitas daya sebesar 700 watt.
\end{abstract}

Kata kunci: Biogas, Pembangkit Listrik Tenaga Biogas, Digester, Digester Balon

\begin{abstract}
Sei Temiang Livestock in Batam, produce roundabout $\pm 50 \mathrm{~m}^{3}$ of cow faeces each month. Usually, some of this waste is taken away by villagers to be used as raw material of fertilizer. To increase its value, the excrement can be utilized as source of alternative energy before the remnants are applied as organic manure. This research use balloon type as the digester of biogas power plant due to reasons such as simple installation, easy to be overhauled, and the cost is quite affordable. This prototype use a mixture of cow excrement and water with proportion of 1:1. Gas equivalent to 624 litre can be gained from 1 plastic drum which is able to turn on the electricity for 35 minutes with power capacity of 700 watts.
\end{abstract}

Keywords: Biogas, Biogas Power Plant, Digester, Balloon Digester

\section{Pendahuluan}

Sei Temiang merupakan area peternakan sapi terbesar di Kota Batam. Peternakan ini memiliki kapasitas hingga sebanyak 300 ekor sapi dengan rata-rata kotoran yang dihasilkan sebesar $50 \mathrm{~m}^{3}$ perbulan.

Selama ini kotoran tersebut diambil oleh warga sekitar untuk dimanfaatkan sebagai pupuk kandang, walaupun sebetulnya, nilai utilitas limbah organik ini bisa ditingkatkan, salah satunya dengan instalasi pembangkit listrik tenaga biogas.

Sementara itu, naiknya harga bahan baku fosil menyebabkan manusia mencari alternatif energi lain yang efisien dan ekonomis.[1-5] Sumber energi listrik yang ramah lingkungan juga menjadi salah satu isu penting yang harus diperhatikan.[6]

Biogas merupakan gas yang dihasilkan oleh aktivitas anaerobik atau fermentasi dari bahan-bahan organik seperti kotoran manusia dan hewan, limbah domestik (rumah tangga), sampah biodegradable atau setiap limbah organik yang biodegradable dalam kondisi anaerobik. Kandungan utama dalam biogas adalah metana dan karbon dioksida. Biogas yang dihasilkan oleh aktivitas anaerobik sangat popular digunakan untuk mengolah limbah biodegradable karena bahan bakar dapat dihasilkan sambil menghancurkan bakteri patogen dan sekaligus mengurangi volume limbah buangan. Metana dalam biogas, bila terbakar akan relatif lebih bersih daripada batu bara, dan menghasilkan energi yang lebih besar dengan emisi karbon dioksida yang lebih sedikit. [7]

Berdasarkan asumsi dari Pusat Data dan Informasi Energi dan Sumber Daya Mineral Kementerian ESDM (2010) bahwa penggunaan sumber energi fosil yang tidak bijak selain akan menghabiskan cadangan

64 | Jurnal Integrasi | Vol.10 No.2, October 2018, 64-67 | e-ISSN: 2548-9828 
sumber energi juga akan memberikan dampak lingkungan melalui emisi gas $\mathrm{CO}_{2}$ dan gas rumah kaca lainnya. Emisi gas $\mathrm{CO}_{2}$ berdasarkan Skenario Dasar atau Busines as Usual (BAU) akan meningkat menjadi sekitar 1000 juta ton pada tahun 2020 dan akan terus meningkat menjadi 2129 juta ton pada tahun 2030. Berdasarkan scenario mitigasi emisi gas $\mathrm{CO}_{2}$ yang dapat ditekan menjadi 706 juta ton di tahun 2020 dan 1219 di tahun 2030. Menurut sumbernya emisi gas $\mathrm{CO}_{2}$ berasal dari pembakaran batubara $(50,1 \%)$, gas bumi $(26 \%)$ dan minyak bumi $(23,9 \%)$. Sektor industri merupakan penyumbang emisi $\mathrm{CO}_{2}$ terbesar diikuti oleh sektor rumah tangga, transportasi, komersil dan Pertanian, Konstruksi dan Pertambangan (PKP).[8]

\section{Landasan Teori}

Digester biogas adalah salah satu bagian penting dalam proses produksi biogas. Fungsi digester itu sendiri sebagai tempat penguraian kotoran sapi yang akan diendapkan. Adapun jenis digester yang dapat digunakan dalam proses produksi biogas diantaranya adalah:

\section{A. Digester Jenis Fixed Dome}

Digester ini juga sering disebut reaktor Cina, dinamakan demikian karena reaktor ini pertama kali dibuat di cina pada tahun 1930. Digester ini memiliki dua bagian yaitu digester sebagai tempat penguraian kotoran dan bagian penampung gas. Gambar berikut ini merupakan contoh gambar digester tipe fixed dome yang sering digunakan masyarakat Cina dalam pembuatan biogas.[9]

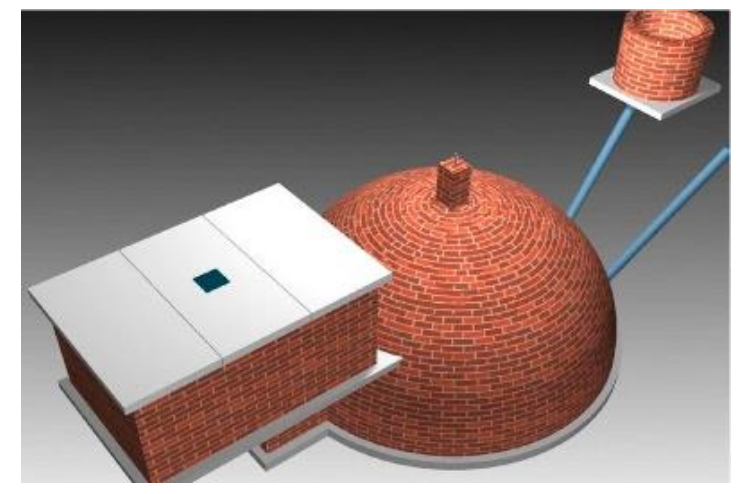

Figure 1. Digester tipe Fixed Dome[10]

B. Digester Jenis floating dome

Digester floating dome atau sering disebut juga digester tipe india. Digester berjenis terapung ini pertama kali dikembangkan pada tahun 1937 di india. Digester ini memiliki bagian yang sama dengan digester tipe cina,perbedaannya terletak pada bagian penampung gas yang menggunakan peralatan bergerak berupa drum sebagai penampung gas metan.[9]

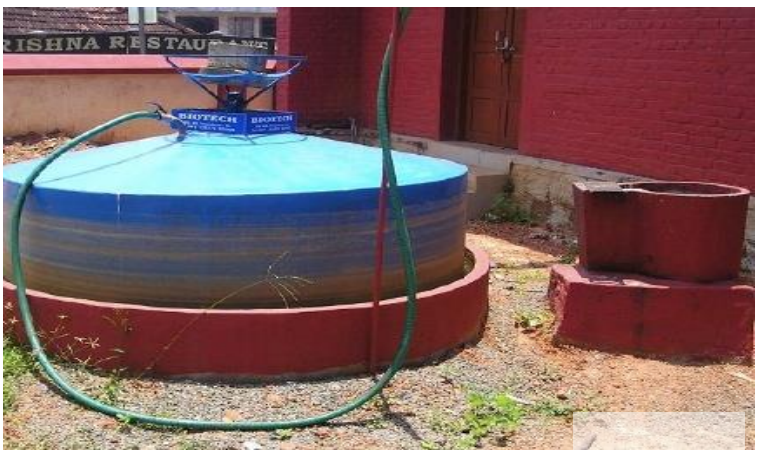

Figure 2. Digester Tipe Floating Dome[11]

C. Digester Jenis Balon

Digester balon merupakan jenis digester yang banyak digunakan pada skala rumah tangga yang menggunakan bahan plastik sehingga lebih efisien dalam penanganan dan perubahan tempat biogas.Digester ini terdiri satu bagian yang berfungsi sebagai digester penguraian kotoran dan penampung gas sementara dalam satu ruang tanpa sekat.

Gambar berikut ini merupakan digester jenis balon dimana digester ini mempunyai dua jenis tangki yang berguna sebagai tempat penguraian kotoran dan penampung gas metan. Tangki penguraian kotoran ini sendiri mempunyai kapasitas $1200 \mathrm{~L}$ dan tangki penampung gas sebesar $100 \mathrm{~L}$. Kedua tangki ini berbahan plastik.[9]

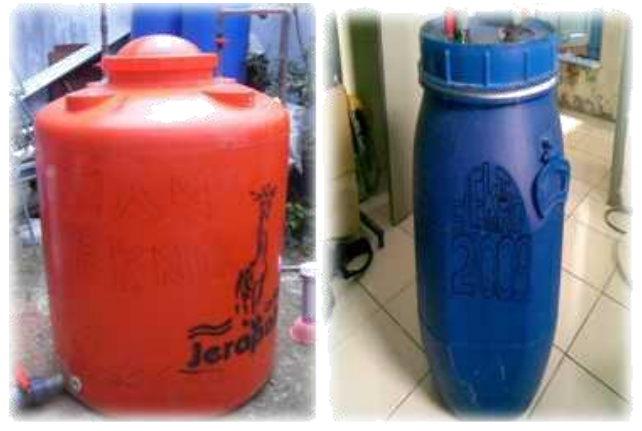

Figure 3. Digester dan tempat penampungan tipe

$$
\text { Balon[9] }
$$

Adapun proses pembentukan gas metan diawali dengan penimbunan kotoran organik dalam tempat penampungan tanpa oksigen. Substrate dari kotoran ini diubah menjadi karbohidrat, lemak, protein dan asam nukleat dalam proses hidrolisis. Selanjutnya, dilakukan proses pengasaman yang mengubah struktur karbohidrat menjadi gula, asam lemak, asam amino dan basa. Baik proses hidrolisis dan pengasaman dilakukan dalam kondisi fakultatif, menggunakan bakteri anaerobik berupa acetobacter. Proses ketiga merupakan metanogenesis yaitu 
pengubahan asam asetat, hidrogen, asam formik dan bikarbinat menjadi gas $\mathrm{CH}_{4}$ dan $\mathrm{CO}_{2}$. Proses terakhir ini melibatkan bakteri anaerobik methanobacter.[12]

\section{Perancangan Alat}

Desain pembangkit biogas bisa dilihat melalui gambar berikut ini.

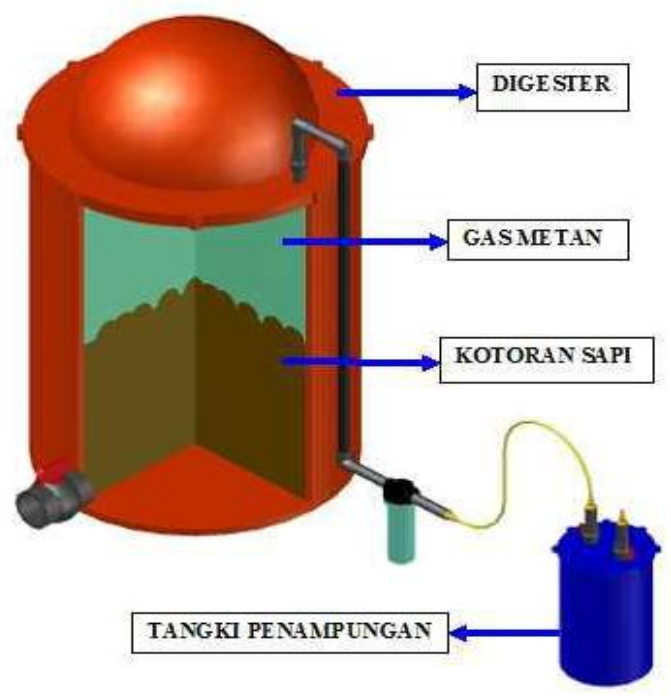

Figure 4. Proses Produksi Biogas

Biogas terbentuk dalam proses penguraian yang terjadi di ruang kedap udara dengan suhu penguraian antara $30^{\circ} \mathrm{C}-55^{\circ} \mathrm{C}$. Proses produksi biogas dengan menggunakan digester tipe balon yang berukuran 1200 liter sebagai tempat penguraian kotoran dan tangki penampungan sebesar 100 liter sebagai tempat penampungan gas metan.

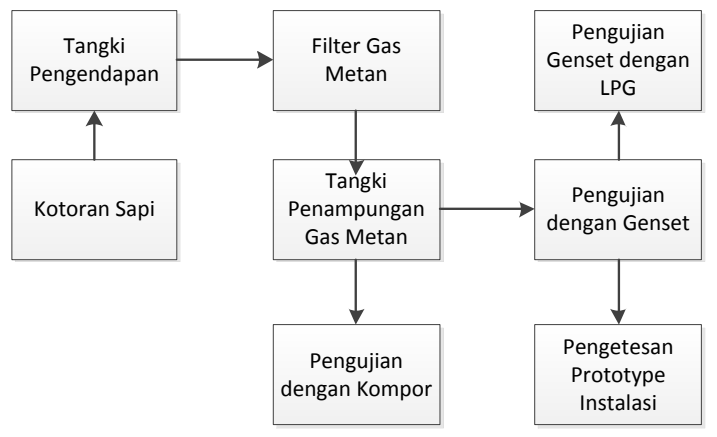

Figure 5. Diagram Blok Sistem Kerja

Secara umum,sistem kerja dalam produksi biogas bisa dilihat dari pada gambar diagram di atas. Bahan utama yang digunakan adalah kotoran sapi. Kotoran yang masih segar ditampung dalam digester selama 1 bulan untuk proses penguraian kotoran oleh bakteri anaerob. Gas metan yang telah tertampung dalam tangki penguraian kemudian dialirkan ke filter gas untuk proses pemurnian gas. Gas metan yang telah melalui filter kemudian akan ditampung di tangki penampungan lalu diuji coba dengan kompor gas mini. Pengujian selanjutnya menggunakan genset, dimana gas metan difungsikan sebagai pengganti bahan bakar LPG. Adapun pengujian terakhir, output dari generator yang berupa tegangan listrik kemudian dialirkan ke dalam instalasi listrik yang telah dibuat.

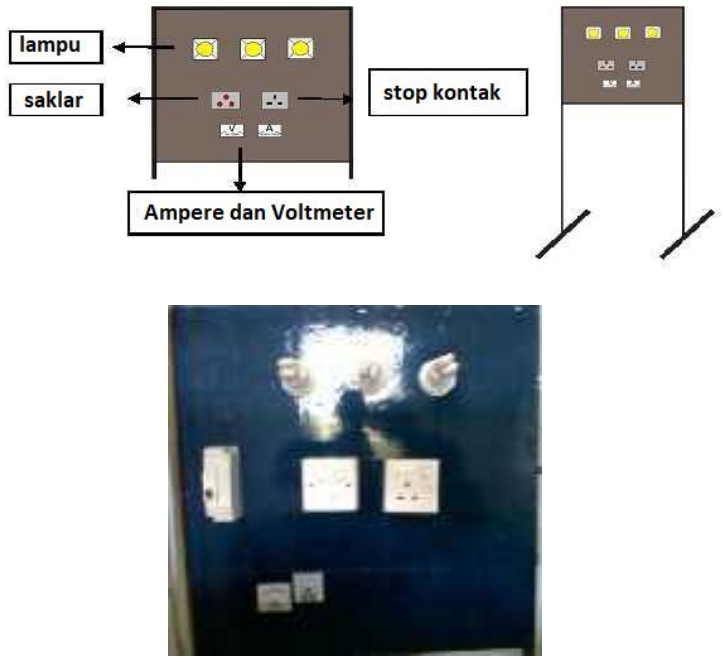

Figure 6. Desain dan Prototype Instalasi Listrik

\section{Hasil dan Analisis}

Dalam pembuatan pembangkit listrik tenaga biogas ini, ada beberapa pengujian yang harus dilakukan untuk setiap alat.

\section{a. Pengujian Genset CC700 Series}

Pengujian ini dimaksudkan untuk mengetahui bisa tidaknya genset ini menggunakan bahan bakar gas LPG maupun gas metan, dengan cara memasukan saluran gas LPG ke katup input bahan bakar genset sebagai pengganti gas metan untuk sementara waktu. Setelah saluran gas LPG dipasang, genset bisa langsung dihidupkan dengan cara menarik atau mengengkol tali penarik yang berfungsi sebagai starting manual.

\section{b. Pengujian Gas Metan}

Pengujian ini dilakukan dengan tujuan untuk mengetahui apakah kandungan gas metan yang terdapat pada digester sudah dapat digunakan sebagai bahan bakar atau tidak. Langkah ini dilakukan dengan menyalurkan gas metan ke kompor gas, lalu kompor gas ini dinyalakan dengan pemantik. Dari pengujian ini diketahui bahwa kompor sudah bisa menyala dengan bahan bakar gas metan.

\section{c. Pengujian Secara Keseluruhan}

Alat ini pertama kali diuji coba dengan menggunakan kompor gas mini untuk mengetahui ada atau tidaknya gas yang dihasilkan oleh digester. Melalui pengetesan dengan kompor, diketahui bahwa gas metan bisa memberikan nyala api. Selanjutnya dilakukan 
pengujian alat dengan menggunakan generator. Pengujian dilakukan dengan menyalurkan gas LPG ke generator kemudian generator tersebut dinyalakan (starter). Hal ini dilakukan karena generator tersebut membutuhkan tekanan yang besar untuk nyala pertama dan gas yang dihasilkan digester tidak memiliki tekanan yang cukup untuk keperluan tersebut. Setelah generator menyala, dilakukan perpindahan dari gas LPG ke gas metan secara bersamaan agar aliran gas tidak terputus. Setelah dilakukan perpindahan sumber gas tersebut, generator bekerja dengan sumber berupa gas metan yang telah dihasilkan oleh digester.

Tabel berikut ini menunjukkan keluaran yang didapatkan dalam pengujian.

Table 1. Keluaran yang didapat saat pengujian

\begin{tabular}{|l|l|}
\hline Tegangan & $220 \mathrm{~V} \mathrm{AC}$ \\
\hline Daya & $700 \mathrm{Watt}$ \\
\hline Durasi generator bekerja & 35 menit \\
\hline
\end{tabular}

Selanjutnya keluaran dari generator dihubungkan ke prototipe instalasi listrik yang terdiri dari 3 lampu TL sebagai beban dan 1 stop kontak untuk beban tambahan berupa kipas angin. Dengan jumlah total 4 beban tersebut, generator dapat bekerja selama 35 menit.

\section{Kesimpulan}

Dalam pengujian digester tipe balon, genset memerlukan energi starter berupa LPG sebelum berpindah ke gas metan hasil produksi dari pembangkit biogas. Di samping itu, untuk digester tipe balon dengan volume total 100 liter, hanya cukup untuk menyalakan listrik selama 35 menit dengan rating daya sebesar 700 watt dengan proses produksi dalam kondisi anaerob selama 1 bulan penuh. Untuk memperoleh hasil yang lebih baik, disarankan penggunaan tangki digester yang lebih besar sehingga kontinuitas suplai gas metan tetap terjaga, sesuai dengan penelitian sebelumnya bahwa dengan volume tangki $0,8 \mathrm{~m}^{3}$ mampu untuk menghasilkan gas enam kali lipat lebih besar dengan waktu retensi yang relatif sama[13].

\section{References}

1. Singh, K.J.S., S.S, Comparative study of economics of different models of family size biogas plants for state of punjab, India. Energy Convers. Manag., 2004. 45: p. 1329-1341.

2. Amigun, B.S., R.; Von Blottnitz, H, Commercialisation of biofuel industry in Africa: A review. Renew. Sustain. Energy Rev., 2008. 12: p. 690-711.
3. Pagar Savita, D., Design, Development and Performance Evaluation of Biogas Stoves. Maharana Pratap University of Agriculture and Technology: Udaipur, India, 2008.

4. Zhou, Z.W., W.; Chen, Q.; Chen, S., Study on sustainable development of rural household energy in northern China. Study on sustainable development of rural household energy in northern China, 2008. 12: p. 2227-2239.

5. Karthik Rajendran, S.A.a.M.J.T., Household Biogas Digesters-A Review. energies, 2012. 5: p. 2911-2942.

6. Qoriatul Fitriyah, D.I., Prediksi Beban Listrik Pulau Bali Dengan Menggunakan Metode Backpropagasi. Semnasif, 2011. 1(5): p. 1174.

7. Alwathan, M., Ramli Thahir, PENGURANGAN KADAR H2S DARI BIOGAS LIMBAH CAIR RUMAH SAKIT DENGAN METODE ADSORPSI. Konversi, 2013. 2(1).

8. Fianda Revina Widyastuti, P., Hadiyanto,

POTENSI BIOGAS MELALUI

PEMANFAATAN LIMBAH PADAT PADA

PETERNAKAN SAPI PERAH BANGKA

BOTANICAL GARDEN PANGKALPINANG.

EJournal Undip, 2013.

9. Irawan, D., RANCANG BANGUN PEMBANGKIT LISTRIK TENAGA BIOGAS UNTUK DAERAH SEI TEMIANG. 2012.

10. Lam, J., SNV at NBP Dhaka. 2007.

11. Mueller, NGO Biotech India. 2007.

12. Ulrich Stohr, U.W., Biogas Plants in Animal Husbandry A Practical Guide. 1989(Informatica International, Inc.).

13. KHASAN S. KARIMOV, A.M.A., Solar Biogas Digester with Built-In Reverse Absorber Heater. 2011. 